\title{
PENDAMPINGAN BACA TULIS AL-QUR'AN
}

\author{
EKA SERLI PRATIWI \\ 9173770410318 \\ ekaserlipratiwii@gmail.com
}

1. Bentuk Kegiatan

$>$ Belajar baca tulis Qur'an TKA/TPA Al-ikhlas dan mengaji bersama santri.

2. Lokasi

$>$ Posko KKLP dusun palloli desa Bontocini kecamatan rumbia.

3. Hari/Tanggal dan Waktu

> Selasa 20 oktober 2020 pukul 18:30 - selesai , Jum'at 23 oktober 2020 pukul 18:25 - selesai , Selasa 27 oktober 2020 pukul 18:20 - 19:10.

4. Peserta yang Dilibatkan

> Santri TKA/TPA Al-Ikhlas

> Mahasiswa KKLP STIE STKIP YAPTI Jeneponto

5. Alasan diadakannya

> Alasan diadakan pembimbingan baca tulis Qur'an kepada anak santri adalah karena melihat antusias santri dalam kegiatan belajar mengaji ini sangat besar sehingga kami berinisiatif untuk mendapingi santri dalam mengajarkan serta memperbaiki makhroj huruf dan tajwidnya.

6. Tujuan dan Manfaat

> Tujuan dan Manfaat kegiatan ini adalah untuk mendampingi serta mengajarkan pelafalan huruf hijaiyah yang benar. 


\section{Deskripsi Kegiatan}

> Kegiatan ini dilaksanakan ba'da maghrib sampai sebelum isya dan berlangsung selama kurang lebih 30 menit. 